\title{
The legal battle for the universal access to primary education in Swaziland
}

\section{Serges Djoyou Kamga}

Thabo Mbeki African Leadership Institute, University of South Africa

\begin{abstract}
SUMMARY
This article examines the extent to which Swaziland complies with its obligation under international law and section 29 of its Constitution to implement the right to primary education. To this end, it examines two court decisions by the same name in different years, related to the same set of facts, but with different outcome. The case name is, Swaziland National Ex-Miners Workers Association v The Minister of Education (2009), which epitomises the legal battle for universal access to primary education. In its analysis of the Ex-Miners Workers Association case, the article seeks to draw lessons from the 20 years of the Centre for Child Law's (CCL) education litigation in South Africa. From the CCL's litigation experience, the Swaziland courts should learn how to craft structural interdicts that can enable them not only to comply with the law, but to also consider the broad socio economic and political environment.
\end{abstract}

\section{Introduction}

The right to primary education is indispensable for human development. It is an enabling right as it empowers the beneficiary not only to develop himself or herself, but to contribute to the development of their community. ${ }^{2}$ The prominence of this right is highlighted by its recognition in various human rights instruments at the global ${ }^{3}$ and regional ${ }^{4}$ levels as well as in most national constitutions including the 2005 constitution of Swaziland. It is worth noting that Swaziland is party to these international and regional agreements seeking to foster the right to education. Under article 29(6) of this Constitution,

1 Aspects of this article build on Skelton and Kamga "Broken promises: constitutional litigation for free primary education in Swaziland" Journal of African Law vol 61, No 3 (2017) 419-442.

2 Brown v Board of Education of Topeka (1954) 347 US 483 at 493; Skelton "Strategic litigation impacts: Equal access to quality education" Open Society Justice Initiative, Open Society Foundations Education Support Program (2017) 22;

3 The International Covenant on Economic, Social and Cultural Rights, (General Assembly Resolution 2200A (XXI) of 16 December 1966, entry into force 3 January 1976, arts 13(2)(a) and 14); The Convention on the Rights of the Child (Art 28), and the 1960 United Nations Educational and Cultural Organisation (UNESCO, art 4 a).

4 Art 17 African Charter on Human and Peoples' Rights, adopted on 27 June 1981 by the OAU Assembly, OAU Doc CAB/LEG/67/3 Rev 5 (1982); Art 11 African Charter on the Rights and Welfare of the Child, OAU Doc CAB/LEG/ 24.9/49 (1990), entered into force on 2 November 1999.

How to cite: Kamga 'The legal battle for the universal access to primary education in Swaziland' 2019 De Jure Law Journal 540-556 
"[e]very Swazi child shall within three years of the commencement of this Constitution have the right to free education in public schools at least up to the end of primary school, beginning with the first grade".

However, this global recognition of the universal right to primary education does not always translate into reality on the ground. Kishore Singh, the special rapporteur on the right to education explains as follows: "the enjoyment of the right to education is often least accessible to those who need it most - disadvantaged and marginalized groups and, above all, children from poor families". 5

It is in this context that this article examines the extent to which the constitutional "promises" 6 of Swaziland on the right to universal access to primary education is given effect to. The article argues that these promises are not respected. To this end, it examines two court decisions by the same name in different years, related to the same set of facts, but with different outcome. The case name is, Swaziland National Ex-Miners Workers Association v The Minister of Education (2009), which epitomises the legal battle for universal access to primary education. ${ }^{7}$ Swaziland is a fascinating case study because as indicated above, its constitution provides for universal primary education with a timeline from its commencement, and this is unique.

In its analysis of the legal battle for universal access to primary education, the article relies on three related factors namely the case study, constitutionalism and remedies. Through the examination of case law, the article demonstrates that when a core principle of constitutionalism such as the separation of power is lacking, it is almost impossible to protect the right to primary education because the judge is likely disregard normative correctness to the benefit of pragmatism, or is likely to "balance interest" to detriment of "right maximising approach". 8 Nonetheless, it also shows that the quality of remedies, especially structural interdicts can lead to an effective protection of the right as they enable the court to reconcile normative correctness and pragmatism.

In its analysis of the Ex-Miners Workers Association case, the article seeks to draw lessons from the 20 years of the Centre for Child Law's (CCL) education litigation in South Africa. From the CCL's litigation experience, the Swaziland courts should learn how to craft structural interdicts that can enable them not only to comply with the law, but to also consider the broad socio economic and political environment. In making its case, the article relies on the doctrinal and normative method.

5 Singh "Justiciability of the right to education" Report of the Special Rapporteur on the Right to Education (2013) UN GA A/HRC/23/35, 3.

6 Skelton and Kamga (2017)419.

7 Swaziland National Ex-Miners Workers Association and Another $v$ The Minister of Education and Others [2009] civil case no 335/09 (16 March 2009). Swaziland National Ex-Miners Workers Association v The Minister of Education and Others, [2010] civil case no 2168/09 (19 January 2010

8 Gerwitz "Remedies and Resistance" Yale Law Journal vol No 92(1983) 591. 
This approach entails an analysis of the case law and normative argument about its implications for strategic litigation.

The article will be divided into five parts including this introduction. The second parts will unpack the cases that give rise to ligation on the right primary education to understand the courts approaches vis a vis the international regime of the right under discussion. The third part of the article will analyse the constitutional landscape which informs the ultimate decision of the courts. It argues that in the context of "Constitution without constitutionalism" or a futile constitutionalism, the enjoyment of human rights and the right to primary education is an illusion. The fourth part of the article examines possible remedies that could have been offered with consideration of the separation of powers doctrine. Drawing from the CCL's experience, it demonstrates that the court through structural interdicts or supervision can ensure the protection of the right to primary education without violating the law and remain pragmatic. The final part of the article provides concluding remarks.

\section{Swaziland National Ex-miners Workers Association $v$ the Minister of Education: Facts and decisions}

In total disregard of section 29(6) of the Constitution that compels the government to ensure free universal access to primary education within 3 years of the commencement of the Constitution, many learners did not enjoy the right after the stated timeline has passed. Consequently, in 2009, affiliates of the Swaziland National Ex-Miners Workers' Association decided to take the state to court to claim the right to education for their children and grandchildren. In court, the association requested a declaratory order recognising that the right to education is free and subject to immediate realisation. To substantiate their arguments, the applicants requested a combined reading of article 29(6) and section 60(8) of the 2005 Constitution which further strengthens the state's obligation on the right to education in these terms: "[w]ithout compromising quality, the State shall promote free and compulsory basic education for all and shall take all practical measures to ensure the provision of basic health care services to the population". "In addition, the applicants highlighted the fact that the 3 years timeline had elapsed and many children still did not have access, and this was constituted in itself a violation of the Constitution. ${ }^{10}$

The respondents comprising the minister of education, the prime minister, the Swaziland government and the attorney general argued

92005 Constitution, sec 60(8) is a principle of state policy and, as such, nonjusticiable.

10 Swaziland National Ex-Miners Workers Association (2009), at 16 
that there was no violation of the right at issue. In their view, the right to primary education did not amount to "the provision of primary education free of charge to the parents of children", ${ }^{11}$ but instead the adoption of a comprehensive programme seeking to establish an enabling context in which the quality of education is not compromised. ${ }^{12}$ According to the respondents, the provision of textbooks, stationery, schoolbooks, competent teachers, classrooms and other infrastructure was an indication that the government was ensuring the right to universal primary education. ${ }^{13}$ Furthermore, not only the respondents indicated that in their efforts to ensure free universal primary education, they paid school fees for the orphans and other vulnerable learners, they also noted that the right to primary education should be submitted to the regime of progressive realisation and availability of resources as other socioeconomic rights. ${ }^{14}$

Rejecting this view, the court cautioned against a reading of free education that "will only do violence to the language, be artificial and in reality be absurd", ${ }^{15}$ and ultimately distort the spirit of the Constitution. ${ }^{16}$ Consequently, the court found for the applicants these terms:

"I make a declaration that every Swazi child of whatever grade attending primary school is entitled to education free of charge, at no cost and not requiring any contribution from any such child regarding tuition, supply of textbooks, and all inputs that ensure access to education and that the said right accrued during the course of the period of three years following the coming into force of the Constitution. I make a further declaration that the third respondent being the Government of Swaziland has the obligation to provide education free of charge, at no cost, to every child so entitled."17

As correctly argued by Skelton and Kamga, this decision complied with the international regime of the right to primary education ${ }^{18}$ which makes primary education "compulsory and available free to all". ${ }^{19}$ If this is not applicable in the country at the time it becomes party to the Covenant, the States has two years "to work out and adopt a detailed plan of action for the progressive implementation, within a reasonable number of years, to be fixed in the plan, of the principle of compulsory education free of charge for all". ${ }^{20}$ It is important to note that Swaziland became party to the ICESCR on 26 March 2004 and the proceedings take place in 2019 or 5 years after the ratification of the ICESCR, and failed to comply

11 Swaziland National Ex-Miners Workers Association (2009), at 8

12 Idem 4.

13 Ibid.

14 Idem, at 9 .

15 Idem, 22

16 Idem, 17

17 Idem, 27-28

18 Skelton and Kamga (2017) 428

19 ICESCR, art 13 (2).

20 Idem, art 14. Also Committee on Economic, Social \& Cultural Rights, General Comment 11 of 1999 on 'the Plans of action for primary education' 
with its obligation to at least adopt a "detailed plan" to give effect to make "primary education compulsory and available free to all".

The decision is also in line with the international regime of the right to primary education because it does no submit primary education to "progressive realisation" which applies to secondary education, but exclusively to primary education to be made available, accessible, acceptable and adaptable. ${ }^{21}$ More importantly, it should be made "compulsory" and "available free to all". 22

Nonetheless, although important in entrenching the role of the court within the three branches of government, ${ }^{23}$ the declaration is not strong enough, as it does not address the situation on the ground. According to Bishop a declaration is "often perceived as a weak remedy because it creates no direct legal consequences". 24 The Declaration is not and interdict or order that prescribes enforcement, but a mere recognition of the right. Mindful of the weakness of the remedy, in 2010, the Swaziland National Ex-Miners Workers Association brought a second High Court application. ${ }^{25}$ In this application, they requested a mandatory order forcing the government to deliver the declared right without delay.

Unfortunately, the second application was thrown out of court as the judge was of the view that the government's programme for free education was "reasonable and satisfactory in view of the limited resources at the disposal of the respondents". 26 For the purpose of this decision, the court highlighted that the right to basic education as located in article 60(8) of the Constitution was a mere principle of state policy and, as such, was non-binding. ${ }^{27}$ In reality, the court made a reversal and surprisingly moved the right to primary education within the realm of progressive realisation and availability of resources. In this regard, it held: "steps taken by the Respondents are in the circumstances reasonable and satisfactory in view of the limited resources at the disposal of the Respondents". ${ }^{28}$ Interestingly, this uncanny decision was upheld by the Supreme Court of Appeal, ${ }^{29}$ that also submitted the right to primary education to the progressive realisation and availability of resources regime. ${ }^{30}$ If this approach were to be used, it was imperative for the court to scrutinise the state's plan of action aiming to secure "the

\footnotetext{
21 ICESCR, art 13 (2).

22 Id, art 13 (2)(a)

23 Bishop "Remedies" in Woolman et al Constitutional Law of South Africa (2012) 9-176 also Eldridge v British Columbia (1997) 151 DLR (4th) 577 (SCC) at para 96 quoted in Bishop, 9-176

24 Ibid.

25 Swaziland National Ex-Miners Workers Association (2010),

26 Id, para 52

$27 \quad I d$, para 17.

28 Swaziland National Ex-Miners Workers Association (2010), above at note 7, para 52. y

29 Swaziland National Ex-Miners Workers Association (2010 appeal), above at note 18.

$30 I d$, paras 16 and 18
} 
progressive implementation of the right to compulsory primary education, free of charge" with attention to "the number of years" for its implantation as well as its "time frame". ${ }^{31}$ Unfortunately, the court failed to examine these international law standards related to the right to primary education. Not only this violates, international law, it also violates the Constitution of Swaziland which provides that "[e]very Swazi child shall within three years of the commencement of this Constitution have the right to free education in public schools at least up to the end of primary school, beginning with the first grade" The Constitution is progressive with explicit timeline that was not respected by the state given that the case was brought to court four years after the commencement of the Constitution. While this decision was a clear violation of international law, it is imperative to understand the possible reasons behind this blatant overlook of international norms.

\section{The ineffectiveness of enforcing the right to primary education where the basics of constitutionalism are lacking}

\section{The notion of constitutionalism: A snapshot}

Constitutionalism suggests a system of government in which the separation of powers between the executive, the legislature and the judiciary as well as judicial review are a reality. It is a system where the affairs of the state are characterised by respect for the rule of law, human rights, good governance, accountability and free and fair elections. Fombad writes that constitutionalism includes the

"idea that a government should not only be sufficiently limited in a way that protects its citizens from arbitrary rule but also that such government should be able to operate efficiently and in a way that it can be effectively compelled to operate within its constitutional limitations." 32

Accordingly, constitutionalism pointers include explicit provisions of freedom and fundamental rights in a bill of rights, the separation of powers, an independent judiciary, the judicial review and the presence of independent institutions to monitor democracy. ${ }^{33}$ In other words, constitutionalism provides an enabling environment in which the independent courts can read the law without fear or favour. It offers an environment in which judicial deference (when it happens), is not

31 Committee on ESCR, General Comment, 11 para 10.

32 Fombad "Challenges to constitutionalism and constitutional rights in Africa and the enabling role of political parties: Lessons and perspectives from southern Africa" 2007, vol 55, No 1 The American Journal of Comparative Law 14.

33 Fombad (2007); Kamga and Heleba, "Can economic growth translate into access to rights? Challenges faced by institutions in south Africa in ensuring that growth leads to better living standards" Sur International Journal (2013) 86 
informed by the subordination of the judiciary to the executive or the legislative, but by the rule of law which compels the judge to avoid getting into the sphere of other powers.

Put differently constitutionalism captures the notion that the government is to be organises through and constrained by a set of constitutional rules. This notion rejects dictatorship or absolutism. 34 According to Waldron, central to the concept of constitutionalism are the notions of "control", "restraint" and "limit" the government coined under the notion of rule of law. 35

But even dictatorship have their constitutions in which the rules that distance themselves from check and balances found in liberal constitutions are not necessarily respected in their context. ${ }^{36}$ In the kingdom of Swaziland, the rule of law may well mean the supremacy of the king within the specific context of the kingdom.

Given that Swaziland is administered by law as well as the custom, people have the right to rely on their custom which enables them to have a constitution in which the King is paramount. This is in line with the idea of a "people having a right to establish their own form of government [that] is logically compatible with their establishment of a nondemocratic constitution or a heavily compromised or truncated form of democracy". 37

However, when a country such as Swaziland ratifies international treaties which foster liberal democracy and commits to comply with them, it cannot refuse to abide by them based on the local context. While local context matters, it cannot be used as a justification to violate ratified treaties, but should be use to give effect to them. Failure to comply with these treaties turns a country constitutionalism into a futile one because such constitutionalism supposed to comply with international norms that the country is party to. Put differently agreeing to a specific form of normative standards and their monitoring mechanisms and later rely on a "hybrid system" that negates the principles affirmed in ratified global standards transform that constitutionalism into a futile one.

In south Africa the apartheid system widely condemned took place under constitutional arrangements. The latter could not legitimise apartheid which was a crime against humanity. This is to say that the consideration of local context cannot trump global standards of human rights. In Swaziland, it does not help to provide for the separation of powers in a constitution if in reality there is none or else the fundamental

34 Waldon "Constitutionalism - A Skeptical View" (2010) 4-5 available at http:/ Ischolarship.law.georgetown.edu/hartlecture/4 (accessed 2019-08-18); also Waluchow "Constitutionalism" in the Stanford Encyclopedia of Philosophy available at https://plato.stanford.edu/entries/constitutionalism/.

35 Idem, 18

36 Idem.

37 Idem, 30. 
law symbolises dishonesty for its unethical feature, and this become a futile law.

\section{The futility of Swaziland's constitutionalism and its impact on the enforcement of the right to primary education}

\section{The futility of Swaziland constitutionalism}

Similar to the 1968 Swaziland Constitution characterised by the supremacy of the executive in which the King could appoint members of the executive, legislative and the judiciary, ${ }^{38}$ the 2005 Constitution gives incredible powers to the King. During the constitutional review process, which led to the adoption of the 2005 Constitution, King Mswati III singlehandedly appointed his brother to lead a commission without consultation of the masses. ${ }^{39}$ So, the current recognition of the rule of law and judicial independence is a fallacy because in reality, the king is the alpha and omega of the Swaziland government. He is mandated by the Constitution to act as the head of state, ${ }^{40}$ who may only rely on his cabinet and has no obligation to consider advice or opinion from any advisory authority after a possible consultation. ${ }^{41}$ Moreover, the king has a say on the appointment of members of all states institutions. In addition and interestingly, all his acts under customary function are not open to judicial review. ${ }^{42}$ This prominence of the King is an indication that there is no separation of powers.

As for the appointment of judges, in spite of their normative independence, ${ }^{43}$ and the involvement of the Judicial Service Commission (JSC) on their appointment by the King, the latter is not obliged to

38 For example, under sec 98(1) of the Independence Constitution, "The holder of the office of Chief Justice or any office of judge of the High Court shall be appointed by the King, acting in accordance with the advice of the Judicial Service Commission". The Senate comprised 12 members, six of whom were elected by the House of Assembly, the remaining six being appointed by the king as he wished (Independence Constitution, sec 38(4)).

39 Maseko "The drafting of the Constitution of Swaziland, 2005" 2008 African Human Rights Law Journal 324 - 325.

402005 Constitution, section 64(1)

$41 \quad I d$, sec 66(3) and (4).

422005 Constitution, sec 151 (8) provides: "Notwithstanding subsection (2), the High Court has no original jurisdiction or appellate jurisdiction in matters relating to the office of ingwenyama [chief]; the office of indlovukazi [the Queen Mother]; the authorization of a person to perform the functions of the Regent in terms of section 8; the appointment, revocation and suspension of a Chief; the composition of the Swazi National Council, the appointment and revocation of appointment of the Council and the procedure of the Council; and the libutfo [regimental] system, which matters shall continue to be governed by Swazi law and custom."

43 Constitution of 2005 , section 140 
consider the views of the JSC as he "enjoys discretionary powers on whom to appoint". ${ }^{44}$ In addition, as correctly observed by Skelton and Kamga, "the king enjoys immunity from prosecution and, whenever he obstructs judicial independence, the constitution is silent on what should be done to protect the judiciary from such violation". 45 The domination of the executive on the judiciary is palpable. The International Commission of Jurists (ICJ) writes:

"Swaziland's Constitution, while providing for judicial independence in principle, does not contain the necessary safeguards to guarantee it. Overall, the legislative and regulatory framework falls short of international law and standards, including African regional standards." 46

The power of the king over the judiciary was exposed in 2011 when the JSC dismissed a former High Court judge (Thomas Masuku) for allegedly criticizing the king. ${ }^{47}$ In addition, in the same year a practice directive from the former Chief Justice was unambiguous in prohibiting the registration of lawsuits against the king "directly or indirectly" 48 This specific directive was useful in protecting companies in which the king owns shares or interest against litigations. ${ }^{49} \mathrm{~A}$ similar practice directive enabled the Chief Justice to oversee "sensitive political cases so as to shield the king and his cronies from facing the might of the law".50 Nonetheless, it is important to note that in 2000, many judges resigned in protest against a statement of the prime minister that rejected a court decision finding against the king's brother. ${ }^{51}$ However, judges have not always been resilient in Swaziland. Langwenya writes:

"the judiciary seems to have been subdued through the purging of noncompliant judges and the rewarding of those who can and do toe the executive's line. With respect to the doctrine of separation of powers, Swaziland seems to have retrogressed despite a constitutional dispensation that provides a sound normative framework for the doctrine." 52

Overall, it could be argued that although Swaziland has a constitution, it does not have constitutionalism or the latter is simply futile.

44 Kamga and Skelton (2017) 424 also 2005 Constitution, sec 64(3) and (4).

45 Ibid; also see the 2005 Constitution, sec 228(1) and (2).

46 ICJ "Justice locked out: Swaziland rule of law crisis" (international fact finding mission report 2016) 5 .

47 See UN Human Rights Council "ICJ oral intervention on the adoption of the outcome document of the universal periodic review of Swaziland" (15 March 2012) as quoted by Skelton and Kamga, 424

48 ICJ "Justice locked out: Swaziland rule of law crisis" (international fact finding mission report 2016) at 11.

49 Skelton \& Kamga, 424.

50 ICJ "Justice locked out: Swaziland rule of law crisis" (international fact finding mission report 2016) at 11; also Skelton \& Kamga, 424.

51 Chief Mtfuso II (formerly known as Nkenke Dlamini) and Others $v$ Swaziland Government (NULL) [2000] SZHC 82 (5 September 2000).

52 Langwenya "Swaziland: Justice sector and the rule of law" (March 2013) AfriMAP and Open Society Initiative for Southern Africa at 91, available at: http://www.osisa.org/sites/default/files/afrimap_swz_justice_sector_main_ text_web.pdf (last accessed 2019-03-21). 


\section{The impact of a futile constitutionalism on the enforcement of the right primary education: Judicial deference or judicial pragmatism?}

Judicial deference is a core principle of the separation of powers. It posits that judges should not interfere with the domain of the executive or the legislature, but rather defer to them. ${ }^{53}$ According to Mclean, "[d]eference is the court's understanding of its role and the role of other branches of government in adjudication". 54 For instance, judges should stay away from dealing with diplomatic matters or matters related to national security as they do not have expertise on these issues that are squarely within the domain of the executive. Clarifying the meaning of judicial deference, the Constitutional Court of South Africa underlines the need for courts to be mindful of their proficiency in a context of separation of powers where it is important not to venture into unknown spheres as doing so can be as detrimental as judicial timidity. ${ }^{55}$ In highlighting the difference between justiciability which "determine[s] whether the court will make a ruling on a matter or not" 56 and deference, Mclean explains that "constitutional deference is a more subtle balance within the adjudication process determining the weight to be given to the decisionmaking process of other branches of government" 57 Shedding more light on the necessity for judicial deference, former Chief Justice Langa writes that "overly activist judges can be as dangerous for the fulfilment of the constitutional dream as unduly passive judges". 58 This is to say that the judiciary in the exercise of its function should definitely stay away from the areas of competence of other branches of government. Judicial deference is essential to ensure that the executive or legislature are not bogged down by unnecessary prescription by the judiciary.

While the deconstruction of judicial deference seems to suggest that the Swaziland judges deferred the implementation of the right to primary education to the executive that is competent on the matter, the country constitutional context characterised by the supremacy of the king suggests the contrary. This is so because as alluded to early, the king is powerful and enjoys a discretionary power over who becomes judge or not. This huge influence of the king hinders the independence of the judiciary that becomes reluctant to take any decision against him and therefore simply avoids dealing with some matters and defers them to his majesty. In this respect, in the first Ex-miner Association's application where the remedy sought in the form of declaration was weak and almost inconsequent, the court declared the right to primary education

53 For more, on deference, see McLean Constitutional deference, courts and socio-economic rights in South Africa (2009).

54 Idem, 62.

55 Prins v President of the Cape Law Society of the Cape of Good Hope (2002) 1 SACR 431 (CC).

56 Mclean (2009) 26.

57 Ibid.

58 Langa "Transformative constitutionalism" (2006) vol 17, No 3 Stellenbosch Law Review 358. 
as immediately realisable. However, when it was time to call on the king to immediately give effect to the right to primary education as prescribed under international law, the courts displayed their reverence to the king and deferred to him. In this instance the courts use deference as an avoidance strategy or an "avoidance technique" 59 to shun from substantive engagement with the right. According to Ryan, 60

"avoidance techniques encompass a strong preference for relying on legislative and executive measures to define the substance of these rights; creating or expanding procedural remedies (especially remedies that emphasise expanding political access); interpreting the socio-economic rights either at a highly abstract or factually specific level; and limiting direct interventions to cases featuring clearly unconstitutional conduct."

This avoidance gives the impression that deference is problematic. Yet, it is more properly an aspect of the court's stance vis-à-vis the other branches of government and therefore encompasses important positive aspects, such as judicial responsiveness to institutional constraints of competence and legitimacy. According to Hoxter, deference "might sometimes be a desirable judicial stance". ${ }^{61}$ This was also the position of the court in Bato Star Fishing (Pty) Ltd $v$ The Minister of Environmental Affairs and Tourism and Others ${ }^{62}$ where Justice O'regan held that "the Court should take care not to usurp the functions of administrative agencies"63 and "should be careful not to attribute to itself superior wisdom in relation to matters entrusted to other branches of government". ${ }^{64}$ To substantiate this view, Justice Ngcobo held that even in a context where it is imperative to ensure transformation of the South African economy by giving fair share to black owned companies, " $[\mathrm{t}] \mathrm{he}$ duty of the courts in this regard, ... does not extend to telling the functionaries how to implement transformation. That must be left to the functionaries concerned [as] [t]he transformation can take place in various ways". 65

Nevertheless, as mentioned earlier, the Swaziland context, deference was used as an avoidance strategy not confront the "almighty" king. In avoiding to engage with the substantive right to primary education, the court violated the international regime of the right to primary education as this was submitted to progressive realisation based on the availability of resource.

59 Ray "Evictions, aspirations and avoidance" 2015 constitutional court review 174.

60 Idem.

61 Hoxter "The future of judicial review in South African administrative law" (2000) vol 117 No3 South African Law Journal 117(3) 448. For more, also see 449-519.

62 Bato Star Fishing (Pty) Ltd $v$ The Minister of Environmental Affairs and Tourism and Others (CCT 27/03) [2004] ZACC 15; 2004 (4) SA 490 (CC); 2004 (7) BCLR 687 (CC) (12 March 2004).

63 Idem, para 45.

64 Idem, para 48.

65 Idem, para 104. 
Nonetheless, it could be argued that far from showing reverence to the king, the courts were simply pragmatic or realistic. In other words, they were applying the theory of "interest balancing" 66 which entails a broad consideration of the social economic as well as legal contexts. In this perspective, the judge was cautious and decided to take into account the local reality which is not conducive to "rights maximising" 67 approach which is rigorous in seeking normative correctness with a strong focus on the victim and trying to "vindicate the right in the most effective way possible". ${ }^{68}$ In this perspective, as correctly observed by Gewirtzt Judges often have to "accept the reality of ... limits and compromise [their] original objective in order to obtain as much relief as possible"; they have "to enter the world of politics" and, in the end, "to surrender some of their independence”. 69

Put differently, instead of depending on normative correctness, the judges must also ensure the enforceability of their judgements as failure to do so may weaken the judiciary. ${ }^{70}$ In the Swaziland case study, having examined all factors and especially the availability of resources and the possibility of immediate realisation of the right to primary education, the courts were of the view that it was practically impossible for the state to give effect to the right as prescribed under international and the Swaziland Constitution. Therefore, they became pragmatic in their judgements as they had to balance interest.

Nonetheless, it could be observed that pragmatism should not be synonymous with complete normative incorrectness, but rather secured in the nature of remedies, which while complying with normative standard, also enables the state to deliver on its promise in a fair and comprehensive manner. In other words, remedies can be designed to accommodate the rights maximising approach and still balance interest. Essentially the need to balance interest cannot trump or negate the right. In this vein, the purposive approach that seeks "to give effect to the purpose of the right, interpreted in light of the whole Bill of Rights" 71 can be considered. In the Canadian context and particularly in the case of Osborne v Canada (Treasury Board) Sopinka J wrote:

"In selecting an appropriate remedy under the Charter, the primary concern of the court must be to apply the measures that will best vindicate the values expressed in the Charter and to provide the form of remedy to those whose rights have been violated that best achieves that objective." 72

66 Gerwitz (1983) 591

67 Idem.

68 Bishop (2012) 9-59.

69 Gerwitz (1983) 678

70 Singer "Property and coercion in federal Indian law: The conflict between critical and complacent pragmatism" (1990) 63 Southern California Law Review 1822; Easterbrook "Originalism and pragmatism: Pragmatism's role in interpretation" (2008) 31 Harvard Journal of Law and Public Policy 901.

71 Bishop (2012) 9-63.

72 Osborne $v$ Canada (Treasury Board [1991] 2 SCR 170, 346 as quoted in Bishop p 963. 
In the south African context, the courts espouse the purposive interpretation of the right. in Fourie, Justice Sachs held that it was important "to look at the precise circumstances of each case with a view to determining how best the values of the Constitution can be promoted by an order that is just and equitable."73 This is to say that although remedies informed by purposive approach to interpretation the right are not perfect, they can make difference in ensuring the protection of the right.

Besides the purposive approach, the "principled approach"74 is also an option in some cases. Accordingly, as indicated in Hoffmann

"The determination of appropriate relief, therefore, calls for the balancing of the various interests that might be affected by the remedy. The balancing process must at least be guided by the objective, first, to address the wrong occasioned by the infringement of the constitutional right; second, to deter future violations; third, to make an order that can be complied with; and fourth, of fairness to all those who might be affected by the relief.

Invariably, the nature of the right infringed and the nature of the infringement will provide guidance as to the appropriate relief in the particular case. Therefore, in determining appropriate relief, "we must carefully analyse the nature of [the] constitutional infringement, and strike effectively at its source." 75

The principled approach therefore considers several factors. It can be argued that various methods seem to have their limitations. Nevertheless, the following section will examine remedies that can maximise rights without ignoring balance of interest or remedies that can reconcile normative correctness and pragmatism.

\section{Remedies that reconcile normative correctness and pragmatism}

Under section 35(2) of the 2005 Constitution the courts are empower to "make such orders, issue such writs, and make such directions as it may consider appropriate for the purposes of enforcing or securing the enforcement of any of the provisions of this [Bill of Rights]". In other words, the court is allowed to take any decision to ensure that the rights in the constitution are given effect to. In this perspective, they can issue supervisory jurisdiction order and mandatory relief. A supervisory order enables the courts to preserve its jurisdiction over a problem as to enable the aggrieved parties to revert back to it in case of non-compliance. Also known as structural order, a supervisory order can also "require specific performance in which the respondent has to report to a party and / or to

73 Minister of Home Affairs \& Another $v$ Fourie \& Another (Doctors for Life International \& Others as Amici Curiae) as quoted in Bishop p 963.

74 Bishop (2012) 9-63.

75 Hoffmann $v$ South African Airways 2001 (1) SA 1 (CC), 2000 (11) BCLR 1211 (CC) at para 45 quoted in Bishop (2012) 9-64 
the court itself". 76 It enables the court to intrude in other spheres of government as to ensure that beneficiaries fully enjoyed their rights. Unlike a declaratory order which is a mere recognition of a right, the supervisory order enables the court to monitor the effective implementation of the right.

In the second Ex-miners Association case, the court would have strengthened the declaration made in the first application by issuing supervisory order because there was clear evidence that five years has passed since the commencement of the Constitution, and many learners still did not have access to school. This could have been due to the neglect of the issue by the government, the lack of capacity to effectively address the problem or lack of political will. These three criteria identified by Roach and Budlender can trigger supervisory jurisdiction. ${ }^{77}$

From an interest balancing perspective and bearing in mind possible resource challenges confronted by the government, the court should have called on it to table a plan to explain how it intended to address the issue in the long term. In this context, the court should have given for example six months or so to report back to it with steps to be taken including budget consideration to give effect to section 29 of the Constitution.

They should have learned from the South African experience in Madzodzo and Others $v$ Minister of Basic Education. ${ }^{78}$ In this case, after issuing a declaratory order to the fact that the Provincial Department of Basic Education was in breach of learners' right to a basic education, an additional order was provided. It required the department to carry out an audit of the school furniture needs of schools in the Eastern Cape Province, to be filed with the court by a specific date. It also ordered that within 90 days of that audit report being filed, all schools should receive adequate "age and grade appropriate furniture" to enable each child to have his or her own learning space. The court even anticipated the possibility of failure to deliver by the respondent and added another order as follows: "[i]n the event that the respondents envisage that they will not be able to comply with paragraph 4 above, the respondents must make and [sic] application on notice to the applicants" 79 This order definitely ensures that the respondent reports on progress and challenges faced and more importantly updates the applicant on its activities aiming to comply with the court's decision. In the same register, the court appointed a task team mandated to authenticate schools' furniture needs by visiting each school on the list and to report the results to the court by a set date; by another date, all schools had to have been in possession of their furniture. Importantly the task team co-

76 Skelton \& Kamga, 435; also Roach and Budlender "Mandatory relief and supervisory jurisdiction: When is it appropriate, just and equitable?" (2005) 5 South African Law Journal 325.

77 Roach and Budlender, 325.

78 Madzodzo and Others $v$ Minister of Basic Education 2014 (3) SA 441 (ECM).

79 Idem, para $41(5)$. 
ordinator was required to report on a quarterly basis until the process was finalised. ${ }^{80}$

Other South African interesting cases to learn from include the Tripartite Steering Committee and Another $v$ Minister of Basic Education and Others ${ }^{81}$ in which the Court ordered the Provincial Department of Basic Education to review its policy on pupils' transport and report back to it on progress made. ${ }^{82}$ Similarly, after declaring that the failure to deliver textbooks violated the right to education, a court ordered a Provincial Department of Basic Education to deliver the necessary books to learners as a matter of urgency, with a specified commencement date. ${ }^{83}$ The court went further by requesting the department to also develop an urgent remedial plan immediately and the court indicated what should be included in it, such as ascertaining the curriculum gaps that had occurred and the extent to which the quality of teaching had been neglected, and then formulating remedial measures and executing by a date to be stated in the plan. The court also requested the plan to be lodged with it by an agreed date and monthly progress reports to be produced subsequently. ${ }^{84}$

These examples from the South African jurisprudence suggest that claiming that the misleading decisions of the Swaziland court was based on pragmatism is not convincing. On the contrary, it could be argued that Swazi judges did not want to face the might of the king who could get them fired or reprimanded and, the only way out was to rely on judicial dereference. So, while subscribing to Currie and de Waal's caution about intensive reliance on supervisory jurisdictions that are likely to violate the separation of powers, ${ }^{85}$ judicial deference should not be an indication that the separation of powers is flaw like in the case of Swaziland.

In fact given the context of Swaziland, the court could have relied on Rosch and Budlender criteria. ${ }^{86}$ Firstly, this entails the consideration whether there is any reason to believe that the government will not fully comply completely with the order. ${ }^{87}$ In this interrogation, it becomes imperative to check the government record of compliance with court orders $^{88}$ Secondly, the court has to consider the impact of non-

80 This court order was handed down (by agreement) on 16 January 2016

81 Tripartite Steering Committee and Another $v$ Minister of Basic Education and Others 2015 (5) SA 107 (ECG).

82 Ibid.

83 Section $27 v$ Minister of Education 2013 (3) SA 40 (GNP); Basic Education for All and Others $v$ Minister of Basic Education and Others (23949/14) [2014] ZAGPPHC 251, 2014 (4) SA 274 (GP), [2014] 3 All SA 56 (GP), 2014 (9) BCLR 1039 (GP) (5 May 2014); The Minister of Basic Education v Basic Education for All (20793/2014) [2015] ZASCA 198 (2 December 2015).

$84 \mathrm{Ibid}$; for more on this see Skelton and Kamga, 439.

85 Currie \& de Waal The Bill of Rights Handbook (2005) 219.

86 Roach and Budlender 'Mandatory Relief and Supervisory Jurisdiction: When is it Appropriate, Just and Equitable?' (2005) 122 SALJ 325.

87 Bishop (2012) 9-189.

88 Ibid. 
compliance with the order. Question such as the number of persons affected by non-compliance should be considered, issues related to consequence on the society should be examined. ${ }^{89}$

On the first point, the government does not have a reputation to comply with court order. In fact, it is intransigent as it simply refuses to comply with instructions from the judiciary. This was observed in the case of Chief Mtfuso and Another $v$ Swaziland Government and Others. ${ }^{90}$ In this case the applicants successfully appealed against an eviction, signed by Prince Sobandla (the king's brother), the minister of home affairs. The appeal court found for the applicants and granted a suspension to enable them time to exercise their traditional appeal to Ngwenyama [the chief]. ${ }^{91}$ But the Court order was blatantly rejected by the Executive through the prime minister who stated unequivocally that "the government did not recognize the judgment and that it would not be obeyed". ${ }^{92}$ This led to the mass resignation of the Court of Appeal judges resigned en masse. ${ }^{93}$ In this context, encouraging the parties to negotiate and agree on the remedies as it was the case in the South African case of Occupiers of 51 Olivia Road, Berea Township and 197 Main Street Johannesburg $v$ City of Johannesburg and Others ${ }^{94}$ will not be effective, hence the need for court supervision to ensure compliance

Secondly, the impact or consequence of non-compliance will create systemic problem because many children will not be able to attend primary school, and this is not acceptable. Furthermore, the best interest of the child which is a key principle of the international human rights law will also be disregarded. Another compelling argument for supervision in the case of Swaziland is the fact that three years had elapsed since the commencement of the Constitution and the government simply ignored the deadline which is a key factor in assessing the political will of the state. In this circumstance, it could be argued that the state is inattentive to its commitment, and the structural interdict will remind it of such. But if the problem is in "incompetence" 95 or the lack of know-how, a structural interdict will force the state to seek help from experts. So, supervision should not be considered as punishment but "as a means to help government to comply with its constitutional obligations". 96

89 Ibid.

90 Chief Mtfuso II (formerly known as Nkenke Dlamini) and Others $v$ Swaziland Government (NULL) [2000] SZHC 82 (5 September 2000).

91 Chief Mtfuso II (formerly known as Nkenke Dlamini) and Others $v$ Swaziland Government (NULL) [2000] SZHC 82 (5 September 2000).

92 Kamga and Skelton 425;

93 Ibid.

94 See Bishop (2012) 9-180.

95 Idem, 9-189.

96 Idem, 9- 193 


\section{Concluding remarks}

On the backdrop of the constitutional promise on the enjoyment of the right to primary education in Swaziland, the aim of this article was to examine the extent to which this right is a reality in the country. It found that this right had been the subject of a legal battle led by a civil society organisation. This battle is echoed by the Ex-miner association case which initially led to a declaration on the right of primary education as a right to be realised immediately and free of cost. Unfortunately, the second application for enforcement of the right was rejected by the High Court and upheld by the Supreme Court in violation of the international regime of the right to primary education that was submitted to the availability of resources and progressive realisation regime in the process.

It was found that this decision was informed by the futility of Swaziland constitutionalism or a constitutionalism in which the king is the alpha and omega and as result weakens the judiciary and other branches of government. Although judicial pragmatism could have justified the judiciary's reluctance to hold the government accountable, it was also found that the paramountcy of the king could not be neglected and was determinant in judges' attitude. In complying with normative correctness as well as pragmatism, these judges could have learned from the South African experience which echoes the CCL's litigation impact where remedies provided in socio economic rights litigation and the right to education in particular relied on structural interdicts or supervisory jurisdiction which enabled the court to secure normative correctness without forgetting to be pragmatic. This approach enables the government to show its good faith at the minimum. Ultimately, it was found that in a context of futile constitutionalism, the enforcement of human rights and the right to primary education in particular is almost impossible. Nonetheless this can be resolved by the court that is willing to use the right maximising approach without neglecting to balance of interest in its remedies, and this possible through structural interdicts. 